\title{
ЭKOHOMИUECKИE HAYKИ
}

\section{DEVELOPMENT OF BULGARIAN BANKING SYSTEM AFTER THE GLOBAL FINANCIAL CRISIS}

Mihaylova-Borisova Gergana Ilieva Associate Professor, PhD

University of National and World Economy (Bulgaria, Sofia) DOI: 10.31618/ESU.2413-9335.2019.3.58.10-14 ВЛИЯНИЕ ОТРИЦАТЕЛЬНЫХ ИНТЕРЕСОВ НА КРЕДИТНУЮ ДЕЯТЕЛЬНОСТЬ БАНКОВ В ЕВРОЗОНЕ

\author{
Михайлова-Борисова Гергана Илиева \\ Доцент, к.т.н. \\ Университет национальной и мировой экономики \\ (Болгария, София)
}

Коммерческие банки в Болгарии являются основными финансовыми посредниками в стране, играя существенную роль в экономике, предоставляя кредиты и стимулируя потребление и инвестиции, которые имеют решающее значение для экономического роста. В статье анализируется развитие и устойчивость болгарской банковской системы после мирового финансового кризиса. Анализ показал, что, несмотря на негативные последствия мирового финансового кризиса, банковская система в стране оставалась стабильной, хорошо капитализированной и прибыльной.

The commercial banks in Bulgaria are the main financial intermediaries in the country, having substantial role in the economy by providing loans and stimulating the consumption and investments, which are crucial for the economic growth. The paper analyses the development and stability of the Bulgarian banking system after the global financial crisis. The analyses showed that despite the negative effects of the global financial crisis the banking system in the country remained stable, well-capitalized and profitable.

Keywords: banking system, stability, profitability

Ключевые слова: банковская система, стабильность, рентабельность

The banks are the main financial intermediaries in the economy, which tries to attract free financial resources from economic agents in order to transmit them to economic agents, who need these financial resources. In such way, the banking system contribute for higher consumption and investments in the economy, which on the other hand, is crucial for the achievement of higher and stable economic growth. Thus, the development of the banking system and its stability and solvency are crucial for the overall macroeconomic stability and performance.

The financial crisis, which originated from the USA in 2008, became global and affected negatively a lot of countries, including countries in Europe. Bulgarian economy has also been negatively affected especially through trade and foreign capital movement.

The aim of the paper is to analyse the development and stability of the Bulgarian banking system after the global financial crisis.
The paper is structured as follows. In the first section the financial intermediation of the Bulgarian banking system is investigated. Next section analyses the effects of the global financial crisis on the Bulgarian banking system over the stability of the system, as well as the changed behaviour of the system after the crisis. In the final section the main conclusions are represented.

1. Financial intermediation of the Bulgarian banking system.

The financial intermediation of the Bulgarian banking system, measured by the share of the total banking system's assets to GDP, improved significantly in the period after 2004. The global financial crisis has not contributed negatively to the financial intermediation of the system. It increased from $61 \%$ of GDP in 2004 to $96 \%$ in 2008 and $96.8 \%$ in 2017 (Figure 1). The assets of the banking system grew by $7.3 \%$ y/y to BGN 101bn in 2017, mainly due to loans and receivables. 


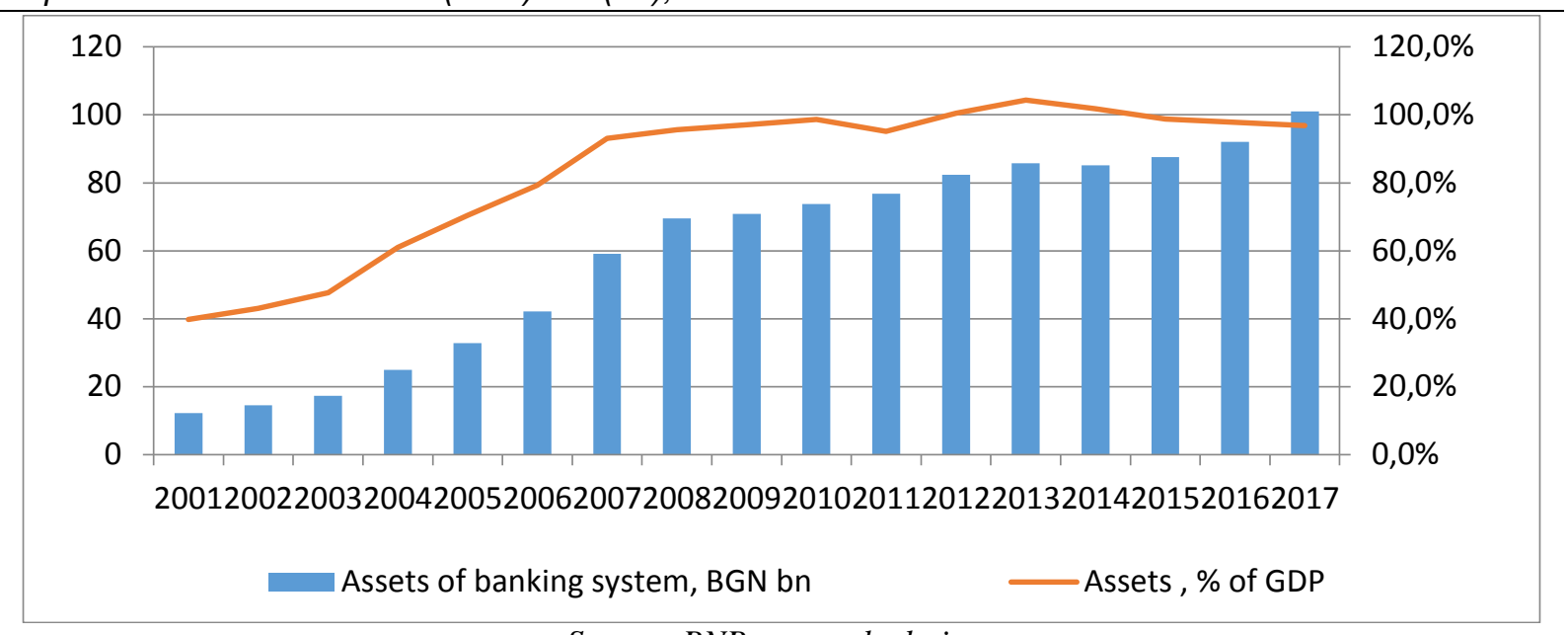

Source: BNB, own calculations

Figure 1. Assets of the Bulgarian banking system

2. Bulgarian banking system after the global financial crisis in 2008.

The Bulgarian banking system remained stable after the global financial crisis, due to the high liquidity of the system and the high capitalization. Despite the fact that the Bulgarian banking system was mainly foreign-owned, the system succeeded to resist on the negative effect of the global financial crisis and liquidity shortage in the European banks.

As a result of the first signals of the financial crisis in 2008 , the foreign liabilities of the banking systems in
Bulgaria started to decrease and stepped down by $7.1 \%$ $\mathrm{y} / \mathrm{y}$ in 2009 versus $53 \% \mathrm{y} / \mathrm{y}$ growth rate in 2008 . The reason for the decelerated growth rate in foreign liabilities was the fact that the foreign banks, owning the Bulgarian commercial banks, started to withdrawal their free resources from the banking system in the country. These financial resources were deposited in the domestic banks before the crisis in order motherbanks to ensure resources for the credit expansion at high interest rates on loans (Figure 2).

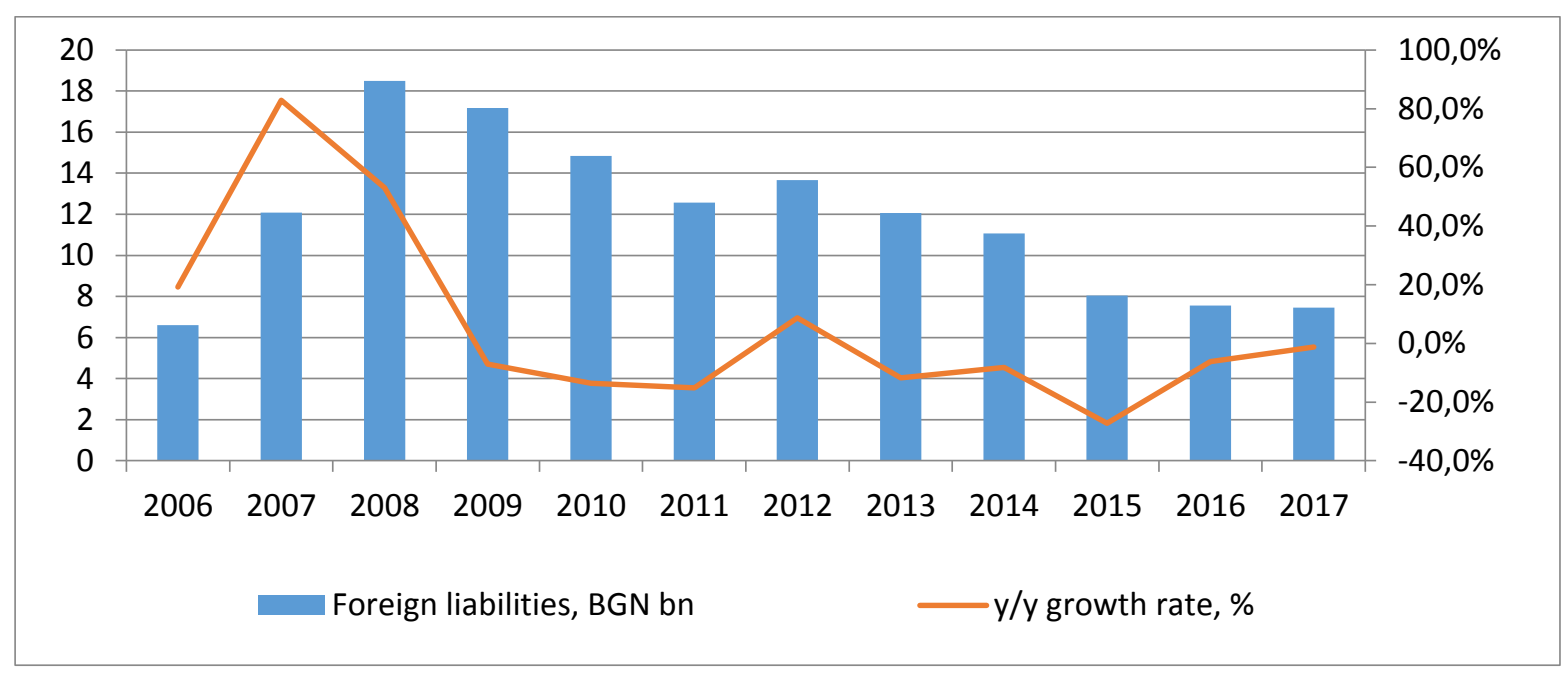

Source: BNB, own calculations

Figure 2. Foreign liabilities of the banking system in Bulgaria

The withdrawal of these foreign resources from the banking system led to decrease in the credit activity of the banking system. The loans, provided by the banking system to non-financial corporations, decelerated to
$2.3 \% \mathrm{y} / \mathrm{y}$ growth rate in 2009 versus $33.1 \% \mathrm{y} / \mathrm{y}$ in 2008 (Figure 3). 


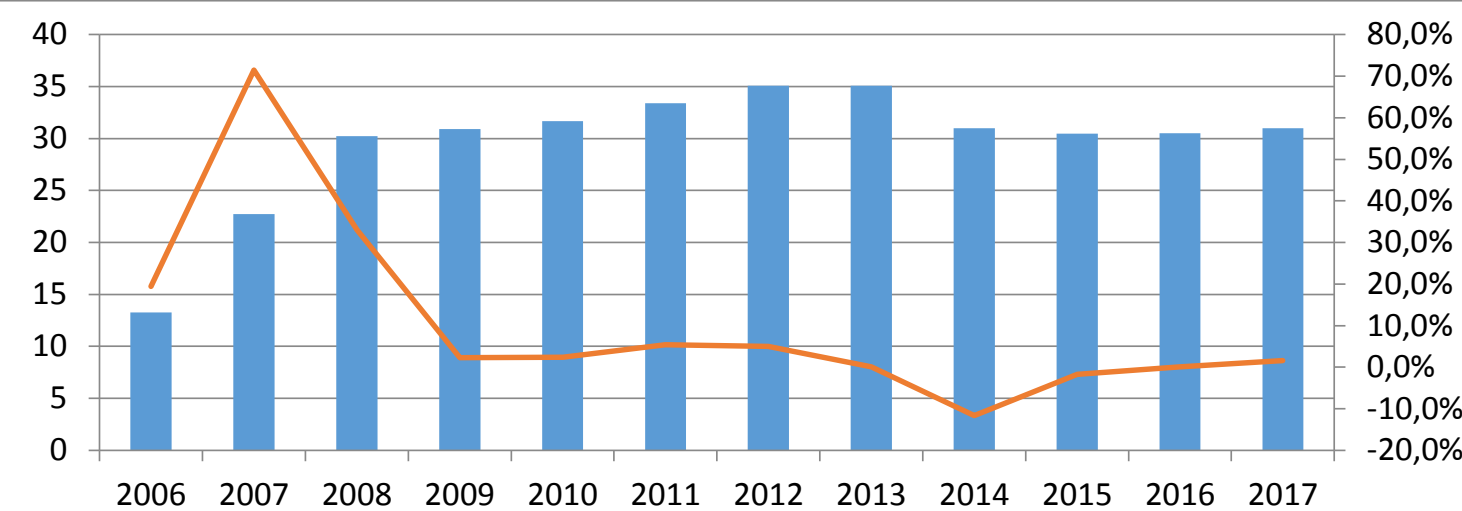

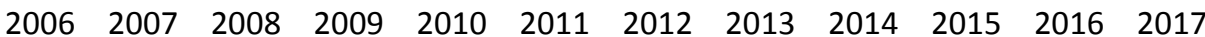

Loans to non-financial corporations, BGN bn

y/y growth rate, $\%$

Figure 3. Loans to non-financial corporations Source: BNB, own calculations

At the same time, the loans to households increased by only $5.8 \% \mathrm{y} / \mathrm{y}$ in 2009 versus $31.4 \% \mathrm{y} / \mathrm{y}$ in 2008 (Figure 4). In the following years up to 2015, the growth rates of loans provided to households were negative, which was related to the lower incomes, higher unemployment and slowdown of economic activity.

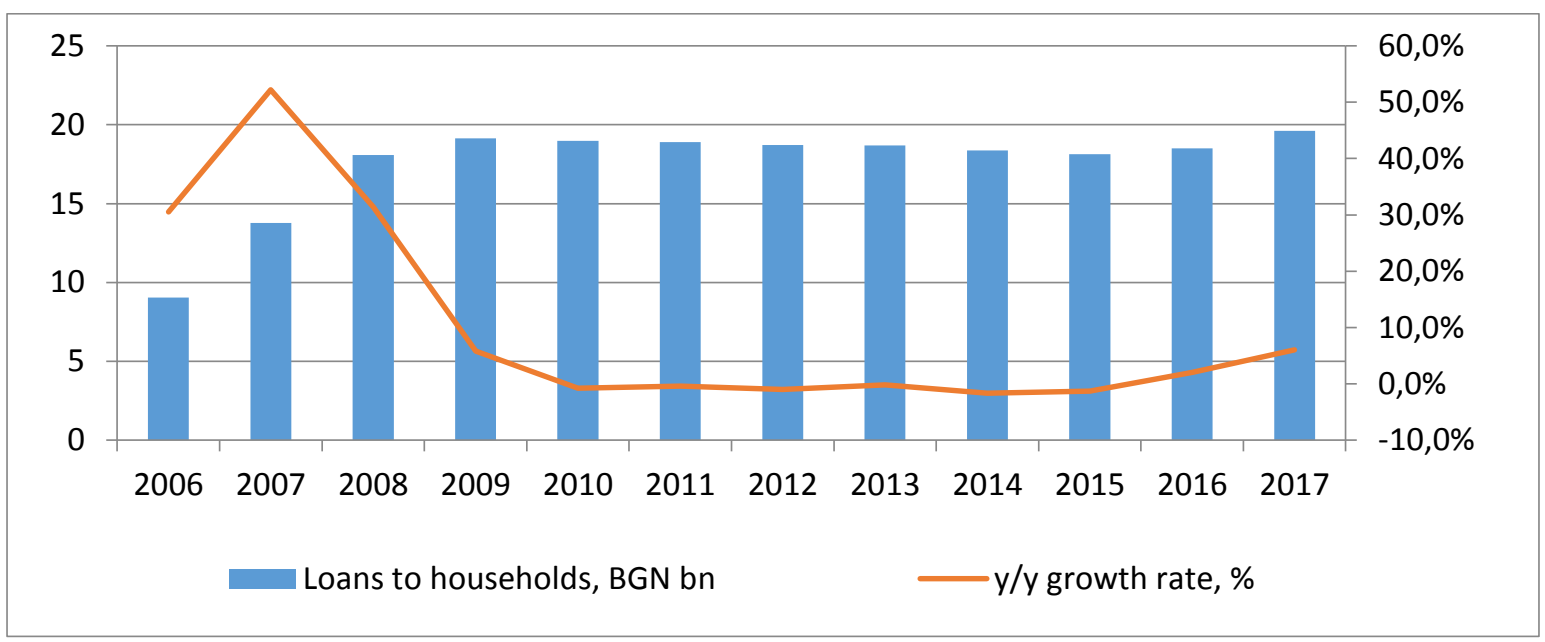

Figure 4. Loans to households Source: BNB, own calculations

In 2014 two banks - Corporate Commercial Bank $\mathrm{AD}$ (CCB) and its subsidiary - the former Credit Agricole - Bulgaria (the banking group CCB) were placed under special supervision, which on the other hand, had substantial negative effect on the loans dynamics. In November 2014 the BNB Governing Council decided to withdraw the license of Corporate Commercial Bank AD for carrying out banking activities in the country and the bank has already bean excluded from the credit institutions ${ }^{1}$. The loans to non-financial enterprises stepped down by $11.6 \%$ y/y to BGN $31 \mathrm{bn}$ in 2014, while the loans to households went down by $1.6 \% \mathrm{y} / \mathrm{y}$ to BGN $18.4 \mathrm{bn}$ in 2014. After 2015 the credit activity of the banking sector in Bulgaria recovered due to favorable economic development, increasing real incomes, growing employment, low interest rates on loans. In 2017 the loans to non-financial enterprises stepped up by $1.6 \% \mathrm{y} / \mathrm{y}$, while the loans to households went up by $6 \% \mathrm{y} / \mathrm{y}$. The acceleration of credit growth

${ }^{1}$ In December 2014, Viktoria EAD (the previous name Credit Agricole) was open to its clients and continued to perform its business under the license it holds. was related not only to the favorable macroeconomic situation, but also to the eased credit standards mainly for consumer loans due to the lowered risk assessments related to the improved outlook for borrowers' solvency, favorable development of housing markets and lower collateral risk $^{2}[1$, p. 25].

After the global financial crisis the banking system in the country became more cautious to the risk assessment and started to provide less loans due to the economic recession and decreasing incomes [2, p. 68]. The economic agents became indebted and had less financial resources to cover their debts. Thus, the non-performed loans of the banking sector started to increase significantly from relatively low levels before the crisis to high levels after that. The non-performing loans of banking system was $2.4 \%$ of the total loans in 2008 and rose to $16.8 \%$ of the total loans in 2013 , being the highest value in the period after $2008^{3}$. The undertaken

\footnotetext{
${ }^{2}$ According to the results of the bank lending survey in the fourth quarter of 2017.

${ }^{3}$ According to the data of the World Bank.
} 
measures by banks to clear their bad loans led to significant improvement in the loans quality. The non-performing loan reached $10.07 \%$ of the total loans in the last quarter of 2017, according to the published data by the Bulgarian bank association [3].

Due to lower credit activity the banking sector in Bulgaria started to increase their liquidity assets after the global financial crisis. The coefficient of liquidity assets climbed from $21.7 \%$ in 2008 to $39 \%$ in 2017 (Figure 5). The coefficient is much larger than the recommended $20 \%$ by the Bulgarian National Bank. The high liquidity of the banks can be explained by the maintenance of higher excess reserves from the commercial banks in the BNB, due to the lack of investment opportunities in abroad and due to the low return on foreign investments.

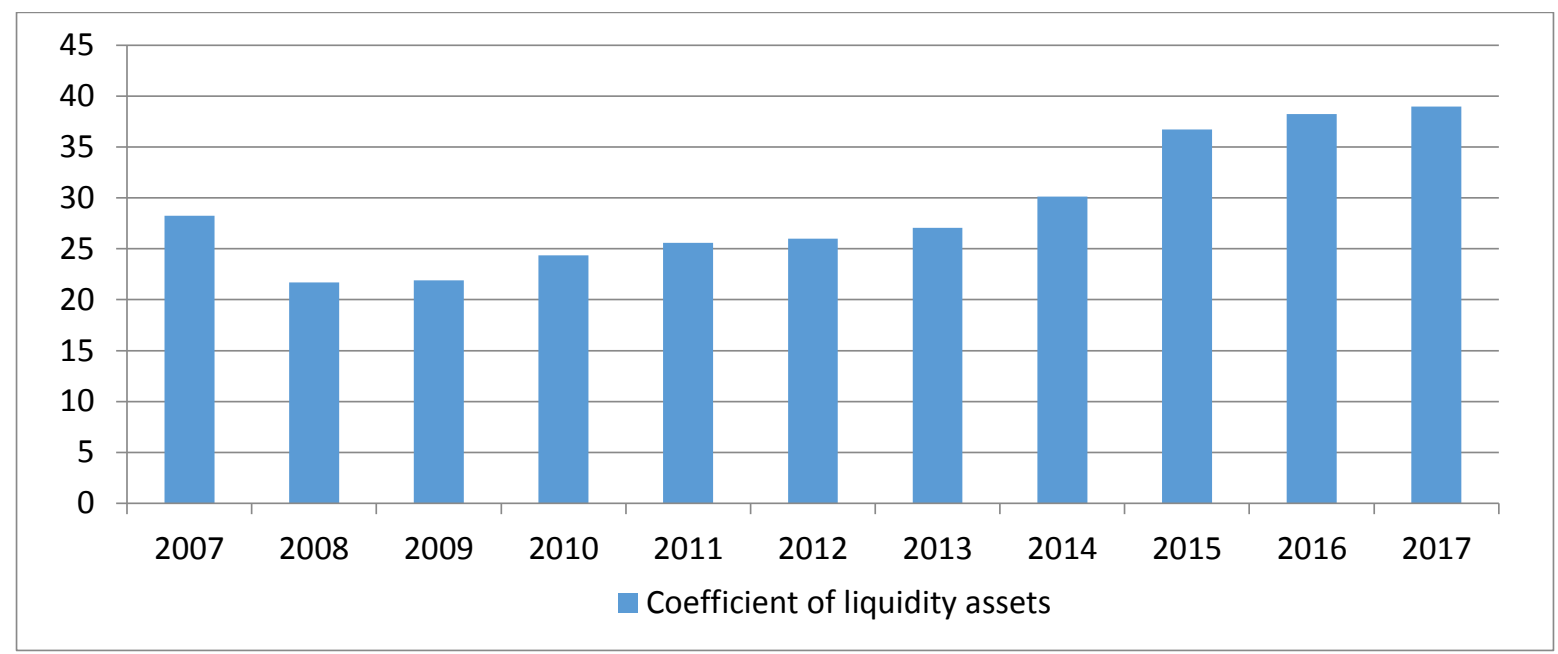

Figure 5. Coefficient of liquidity assets Source: BNB

As a result of the financial crisis the Basel committee on banking supervision started to apply the new capital framework Basel III. The new regulation aimed to improve the ability of banking system to absorb financial and economic shocks, as well as to improve the transparency and management of risks. In the European Union the Basel III has been implemented since 2014 by Directive 2013/36/EU and Capital Requirements Regulation 575/2013.

The Bulgaria also implemented the new capital requirements of Basel III. The banking system in the country was well capitalised even in the outbreak of the global financial crisis. However, the banks in the country improved their capital substantially with the implementation of the new requirements. The capital adequacy ratio rose from $14.9 \%$ in 2008 to $22.1 \%$ in 2017 , being above the minimum regulatory requirements at system level (Figure 6). The ratio was even much higher than the average level for European banks, which was $17.98 \%$ as of September 2017, according to the ECB data.

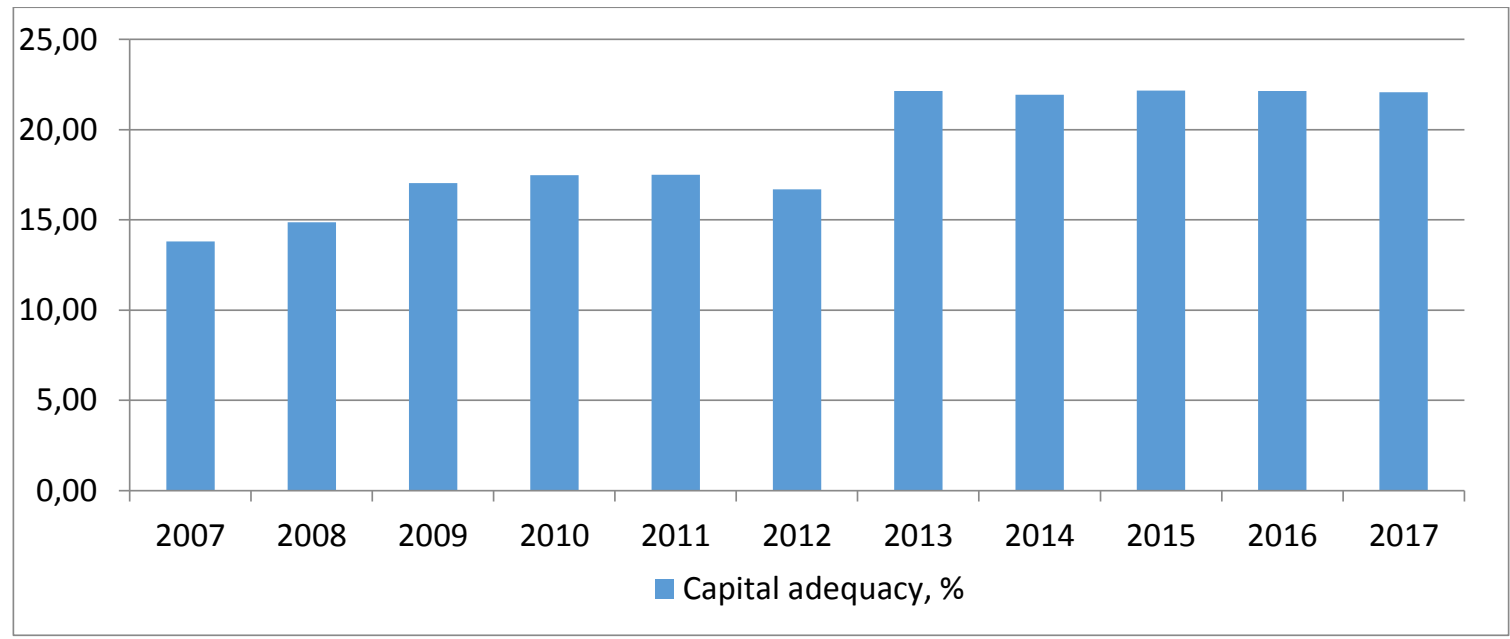

Figure 6. Capital adequacy,\%Source: BNB

After the global financial crisis the lower credit activity led to decline in interest revenues, which on the other hand, decelerated the growth rates of net interest income of banking system. The net interest income rose by $28.4 \% \mathrm{y} / \mathrm{y}$ in 2008 and decelerated to $2.1 \% \mathrm{y} / \mathrm{y}$ in 2009. Actually as a result of the financial crisis and the decline in the key interest policy rates of the big central banks such as the Federal Reserve System and the European Central Bank, the interest rates in Bulgaria also dropped, including the interest rates on deposits and loans. The banks were triggered to change their behaviour as they could not realise the same level of profits 
as before the crisis. They changed their business models and tried to compensate the lower growth rates of net interest income after the crisis by increase in taxes and commissions. Thus, the net income from fees and commissions rose at an average growth rate of $4 \% \mathrm{y} / \mathrm{y}$ in the period 2010-2017, while the net interest income declined by $0.7 \% \mathrm{y} / \mathrm{y}$ in the same period.

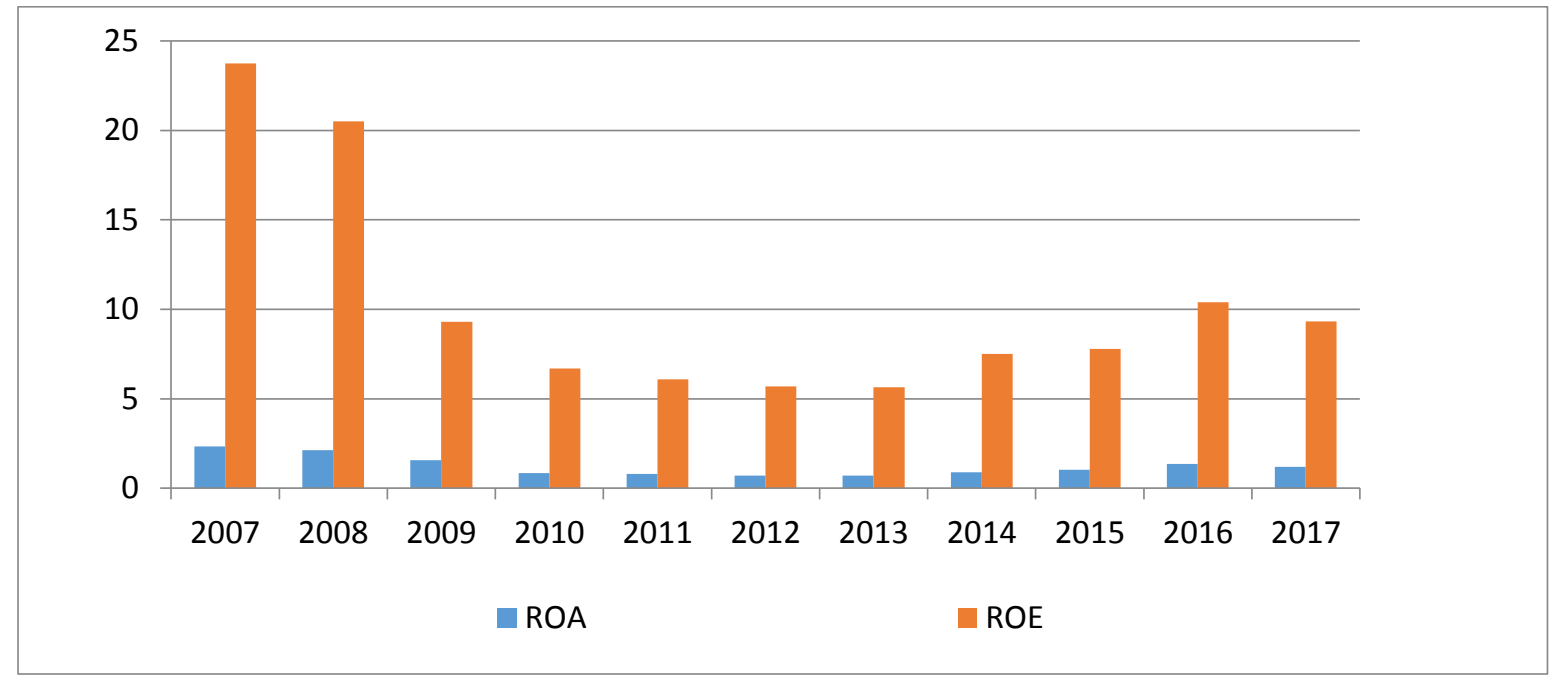

Figure 7. Profitability, \%Source: BNB

The banking system reported significant decline in its net profit in 2009, which stepped down by $43.7 \% \mathrm{y} / \mathrm{y}$ to BGN 780mn. However, in the following years they succeeded to compensate the evidenced declines and the net profit reached $1.17 \mathrm{bn}$ in 2017 . The profitability indicators, return on assets (ROA) and (ROE) declined in the years to 2012 and after that started to increase to reach $1.2 \%$ and $9.32 \%$ in 2017, respectively (Figure 7).

\section{Conclusion}

The financial intermediation of the banking system in Bulgaria declined as a result of the global financial crisis as banks became more cautious in providing new loans. At the same time, the demand of new loans also was limited due to the decreasing incomes and lower savings as a result of the global financial crisis in 2008. Despite the negative effects of the global financial crisis, the banking sector in Bulgaria remained stable and solvent, and succeeded to increase its net profit and profitability indicators in the following years by changing its business model and by increasing taxes and commissions. The banking system rose significantly its capital, keeping the capital adequacy at levels exceeding the regulation. Gradually, the banks in Bulgaria succeeded to recover their credit activity, registering the positive growth rates in their credit portfolio in the last years.

\section{References}

1. BNB, Economic Review, Vol. 1, 2018.

2. Sotirova, E. The Crisis in the Real Economy and the Stability of the Bulgarian Banking System, Economic Alternatives, Issue 1, 2012.

3. Bulgarian Bank Association, Banking system in Bulgaria in 2017 - main accents, 2018 (in Bulgarian). 